\title{
SOCIOLOGIA DO ENSINO MÉDIO: CRÍTICA AO ECONOMICISMO NA POLÍTICA EDUCACIONAL
}

Monica Ribeiro SiLva

A

universalização do acesso ao ensino médio apenas muito recentemente adentrou os horizontes da sociedade brasileira. O reconhecimento de sua condição de educação básica pela Lei de Diretrizes e Bases da Educação de 1996 (LDB 9.394/96) e a ampliação do tempo de obrigatoriedade escolar, assegurada pela EC59/2009, sinalizam na direção de que, cada vez mais, o tenhamos como um direito. Importante conquista para um país que estruturou seu sistema educacional pela ampliação da base e afunilamento do acesso aos níveis mais elevados da escolaridade. Que relações existem entre a constituição do sistema educacional e a constituição mesma desta sociedade?

A obra Sociologia do Ensino Médio: crítica ao economicismo na política educacional nos coloca diante dessa interrogação elegendo um fio condutor que atravessa o conjunto da coletânea: as contribuiçóes que uma sociologia crítica pode dar para o estudo das relaçóes entre sociedade, Estado e educação. O ensino médio é considerado, para essa análise sociológica, por vezes como campo empírico e, outras, como categoria de análise. A compreensão do lugar central que ocupa o ensino médio no cenário educacional, dos mais variados países, deriva do acertado reconhecimento das controvérsias que cercam a definição de políticas para essa etapa da escolarização, bem como dos distintos agentes que protagonizam essa definição.

Outro aspecto nevrálgico presente nas análises da obra diz respeito ao tensionamento entre "informação" e "conhecimento". Tal tensionamento se verifica seja na discussão sobre as finalidades do ensino médio em face da propalada "sociedade da informação e do conhecimento", seja propriamente na produção do conhecimento sobre a educação, produção esta que tem oscilado entre a pesquisa séria e rigorosa, própria de uma sociologia crítica, e a pesquisa de viés pragmático, baseada na lógica da eficiência e da reproduçâo de "experiências bem-sucedidas" que o conceito de "quase-mercado" ajuda a explicar.

* Resenha do livro organizado por Krawczyk, Nora. Sociologia do Ensino Médio. Crítica ao Economicismo na Política Educacional. São Paulo: Cortez, 2014.

** Universidade Federal do Paraná. Curitiba, PR., Brasil. E-mail de contato: monicars@ufpr.br. 
O ensino médio traz a marca da configuração social na qual ele se realiza. Esta afirmação por demasiado óbvia não é empecilho para que Mariano Fernandez Enguita, ao prefaciar o Livro, nos lembre, de forma contundente, a "[...] encruzilhada estrutural do sistema educativo [...]" (p. 10) que representa ainda hoje a escola secundária. Encruzilhada acentuada pelas mudanças ocorridas na passagem do século XX para o XXI e que se traduzem emblematicamente na diversificação dos percursos formativos como aparatos de produção de distinção social. Do ponto de vista do estudante, tal encruzilhada se materializa, dentre outros aspectos, no esgotamento dos atrativos que a escola pode oferecer e na multiplicação das fontes de aprendizagem e de interação por meio dos ambientes digitais. A argumentação desenvolvida por Enguita faz com que, uma vez mais, nos coloquemos diante da indagação sobre a polaridade, complementaridade e/ou oposição entre informação e conhecimento. Qual sociologia poderia nos auxiliar na compreensão de processos - sociais e educacionais - tão complexos?

O eixo que perpassa Sociologia do Ensino Médio - o debate sobre os enfoques destacados na análise e definição de políticas educacionais - merece por parte da sua organizadora uma reflexão privilegiada. No texto de Introdução, intitulado "Conhecimento crítico e política educacional: um diálogo difícil, mas necessário”, Krawczyk assevera o quanto temos estado diante da presença de um enfoque economicista que marca o pragmatismo na pesquisa educacional e confunde, propositadamente, conhecimento com informação, qualidade com eficiência, avaliação com mensuração. A autora nos lembra o quanto nas últimas décadas a definição de políticas educacionais esteve embalada por essa visão economicista, desde, pelo menos, a construção e disseminação da Teoria do Capital Humano na década de 1950.

Em contraponto a essa perspectiva economicista, as análises presentes no livro trazem como referência uma sociologia crítica. Nesta direção, a Sociologia é entendida como a ciência que tem

[...] por objeto de estudo o conhecimento do mundo social, das relaçóes sociais, e como propósito compreender como a sociedade age e se perpetua, suas possibilidades de reprodução e/ou transformaçáo, incorpora necessariamente o estudo das práticas sociais produzidas por relaçóes sociais historicamente determinadas [...]. (p. 24).

Uma perspectiva crítica da sociologia é aquela que toma seu objeto de estudo em sua historicidade e mostra as dinâmicas próprias dos processos de regulação social e suas contradições, bem como os tensionamentos presentes nas relações sociais. 
No campo da educação, uma sociologia crítica, desde Bourdieu (KRAWCZYK, p. 25), é aquela que analisa "[...] as práticas de ensino e comunicação, entre outros, e como esses processos reproduzem as desigualdades sociais, étnicas e de gênero [...]" evidenciando, a um só tempo que, conquanto a escola não seja simplesmente uma instituição a serviço das classes dominantes, tampouco ela é uma instituição neutra. Com base nessa perspectiva analítica é que se estrutura a coletânea.

Sposito e Souza se ocupam de nos fazer entender, a partir dos processos de construção da condição juvenil e das mudanças recentes na sociedade brasileira, a problemática do ensino médio. As autoras mostram que "[...] não obstante a denominada diversidade entre os segmentos juvenis é preciso considerar a existência de processos transversais de natureza social que afetam todos os jovens, quer sejam ou não estudantes [...]" (p. 56). Disso decorre que "reconhecer diversidades implica admitir as transversalidades" e que estas incidem diretamente na relação dos jovens com a escola. As análises feitas no artigo "Desafios da reflexão sociológica para a análise do ensino médio no Brasil" exemplificam uma perspectiva não escolar da reflexão sociológica sobre a escola. (KRAWCZYK, p. 27)

"As relaçôes com os estudos de alunos brasileiros de ensino médio" é o título do capítulo com autoria de Bernard Charlot e Rosemeire Reis. A partir de um estudo comparado, tendo por fonte a Organização de Cooperação e Desenvolvimento Econômico (OCDE), é identificada a situaçáo de atraso em que se encontra o Brasil quando se trata do acesso ao ensino médio. Os autores asseveram que a ampliação do acesso deve vir acompanhada da soluçáo de problemas que aparecem quando um segmento social, antes excluído, adentra o sistema escolar. Nessa direção o texto problematiza o sentido da escola ou a recusa em estudar.

A concorrência entre escolas é um fenômeno universal ou condicionado? A indagação presente no texto de Agnes van Zanten parte da hipótese de que existem relaçóes diretas e indiretas entre os estabelecimentos escolares situados em uma mesma área e que estas relaçóes podem ser tipos diferentes "[...] a depender do fator predominante de regulação: o Estado, o mercado ou a comunidade [...]". (p. 94) O estudo comparado entre países do continente europeu leva a autora a concluir que

[...] os sistemas educacionais que favorecem abertamente o desenvolvimento de políticas de concorrência entre estabelecimentos [...], defendem esse princípio em nome de uma diversidade educacional desejada pelos pais e necessária ao desenvolvimento econômico e social. (p. 121)

De autoria de Maria Alice Nogueira e Wania Guimarães Lacerda o artigo "Os rankings de estabelecimentos de ensino médio e as lógicas de ação das 
escolas - o caso do Colégio de Aplicação da UFV", discute o quanto a indução ao ranking entre escolas suscitados, especialmente, pela divulgação dos resultados das avaliaçóes em larga escala interferem nas dinâmicas de organização das escolas.

As lacunas entre o que se pretende conceituar e as categorias criadas pelas ciências sociais para fazê-lo se assemelha a cavaleiros sem cavalo. A referência é feita por Guillermina Tiramonti aludindo ao desafio do tema a que se propóe desenvolver no capítulo final: "A escola moderna: restriçóes e potencialidades frente às exigências da contemporaneidade". Com vistas a dialogar com vozes que sustentam a incapacidade da escola de ser mediadora da cultura contemporânea, o texto se desenvolve a partir de cinco análises/argumentos: o imperativo da inclusão e a insuficiência do dispositivo institucional moderno; as experiências destinadas à inclusão; a experiência das escolas de reingresso; a exigência da mudança cultural e a experiência das atividades extraescolares; e a gratificação e o desejo como suporte da atividade. Os argumentos nos levam a concluir, com a autora, quando ressalta os limites da escola em oferecer respostas aos imperativos da contemporaneidade: "por um lado, a sua organização baseada num currículo compartimentado" e, por outro "a subjetividade dos jovens que hoje acodem à escola". (p. 204)

Ao finalizar a leitura do livro Sociologia do Ensino Médio, palavras contidas no último capítulo fazem ressonância nos textos anteriores. Necessário, portanto, reproduzi-las para que continuem ecoando e provoque outras análises e que, sobretudo, permita novas perguntas. Ao recuperar as razóes do surgimento da escola na modernidade, Tiramontini nos faz lembrar:

[...] que todas estas funçôes (de integração social, de disciplinamento para o trabalho, de legitimação política) basearam-se numa definição cultural (o Iluminismo, a Ilustraçáo) em referência à qual se organizou a instituição escolar [...]. (p. 188)

O surgimento da escola esteve deveras vinculado aos requisitos da economia. Essa constatação reafirma a relevância e pertinência de Sociologia do Ensino Médio: crítica ao economicismo na politica educacional. Como cavaleiros sem cavalo, esta obra coloca-nos diante do desafio e da possibilidade de compreendê-la para além do economicismo vigente e situá-la no horizonte para além do quase-mercado. 